research rooms. Adjoining the building is a range of glass-houses. Dr. Cody added that about a thousand undergraduates would be accommodated in the new laboratories.

Sir Robert Falconer invited five of the botanical delegates to give short addresses : Prof. A. C. Seward of the University of Cambridge; Prof. K. M. Wiegand of Cornell University; Dr. H. T. Güssow, the Dominion botanist; Prof. Marie-Victorin of the University of Montreal; and Prof. F. E. Lloyd of McGill University. On the following day the honorary degree of Sc.D. was conferred upon Prof. A. C. Seward.

\title{
Plant Products of the British Empire
}

HROM prehistoric times, man has depended to a considerable extent upon plant products, from various economic points of view. Some such products are necessities and others are luxuries. Some which were primarily luxuries have now become, with the great changes in human civilisation and habit, quite essential to human needs. These constant changes and new developments in human needs as regards the vegetable kingdom formed the basis of Sir Arthur Hill's evening discourse delivered at the York meeting of the British Association on Sept. 2, entitled "Plant Products of the Empire in Relation to Human Needs".

The economic botanist seeks to satisfy our human needs, both natural and artificial, and with the tremendous modern developments in human life and habit, his work has become of primary importance. With such a widely scattered Empire, Great Britain is able to supply itself very largely from its own colonies and dominions. Two great 'cravings' of to-day-newspapers and motor cars-are resulting in the destruction of the magnificent forests of Canada and Newfoundland and the extensive plantations of Hevea brasiliensis, the latex of which supplies the raw rubber, in various parts of the Empire.

Fortunately for Great Britain, it is possible, to a great extent within the Empire, to meet the growing demand for various plant products, such as oils and fats, cereals, fruit, animal foods, spices and condiments, beverages, gums and resins, drugs, tobacco, clothing, timber, etc. Certain other industries are fast disappearing, owing to changes in present-day methods and fashions. For example, indigo, camphor, and vanilla are giving place to synthetic substitutes, and cotton and flax have a strong competition in artificial silk. Another group of the Empire's plant resources, often lost sight of, because it does not appear on the world's markets, is native products used chiefly by those who cultivate them. The importance of such
Empire products is scarcely ever realised until such times as famine and crop failure.

During the course of his address, Sir Arthur indicated the original homes, throughout the British Empire, of some of the economic plants. Efforts are still being made to find plants of economic value which can be grown within the Empire, with the ultimate aim of making the Empire self-supporting so far as possible. With the large increase in cultivated areas, complications such as plant diseases have been set up, necessitating the creation of an army of specialistsplant pathologists, entomologists, physiologists, etc. Rust on wheat in Canada, for example, is estimated to destroy annually $£ 5,000,000$ worth of wheat. Every year, in the British Empire alone, insects destroy enough food to supply forty-five million people.

The band of scientific workers attached to the various departments of plant economic and agricultural research throughout the Dominions and Colonies seems a rather formidable one, yet their numbers and cost of maintenance are negligible compared with the toll levied by the diseases they are attempting to overcome.

Since its inception, the Empire Marketing Board has given invaluable help in the war against plant diseases, in research on plant storage, etc., and it has spent $£ 1,235,000$ in grants for research. In many cases, too, research is supported financially by firms which depend upon the various plant products for their raw materials. For example, Messrs. Rowntree, Cadbury, and Fry are supporting the research work on cacao now being carried out at Trinidad.

The scientific problems confronting the Empire in connexion with our supplies of plant products offer a fitting outlet both for private and public munificence, and those who come forward to support the new culture of scientific research and its application to human needs will realise that they are not merely satisfying a noble enthusiasm, but are also fulfilling one of the pressing needs of the Empire.

\section{Electricity Supply in New York}

$\mathrm{N}^{\mathrm{o}}$ city in the world owes more to the advance of engineering than New York, within the boundaries of which are to be found some of the finest bridges, tunnels, subways, high buildings, and power stations ever constructed. The progress of these great undertakings is dealt with from time to time in our own technical journals, and in Engineering for May 13, 27, and June 17 is given a well-illustrated account of the present position of the electrical supply schemes in the city.

Fifty years have elapsed since Edison erected the first public electric supply station in Pearl Street, and that was but the beginning of the great interconnected stations by which New York and the suburbs are served to-day. The greater part of New York is now served by the Consolidated Gas Company, which in 1928 obtained control of five separate undertakings serving an area of 550 square miles and a population of $6,017,702$. In 1927 , the last complete year that the five companies operated as separate concerns, the total output was $4,000,000,000$ kwh. and the plant installed had a total capacity of $1,400,000 \mathrm{kw}$. The capacity of the plant by September 1930 had been increased to $2,009,700 \mathrm{kw}$., and plans are now in hand for a further increase in plant designed to meet a demand which it is estimated will by 1940 be three times as great as that in 1927 .

At present, power is generated in seven stations, of which Hell Gate Station has plant of $605,000 \mathrm{kw}$. and Hudson Avenue Station plant of $560,000 \mathrm{kw}$. At Pearl Street Station direct current was generated and distributed, but to-day all current is generated by alternators, the frequency being either 25 cycles or 60 cycles, frequency changers being installed so that current is available from any station for any part of the system. Interconnexion is to be carried still further by the erection of a transmission line to Schenectady, thus enabling power to be brought to New York from Niagara.

A new problem in the economical distribution of electricity arose with the erection in New York of very high buildings, and in Engiveering for June 17

No. 3280, VoL. 130] 
an account is given of the methods of distribution in the Chrysler Building, $1047 \mathrm{ft}$. high, and the Empire State Building, $1300 \mathrm{ft}$. high. Experience with the Irving Trust Company Building had shown that a saving could be effected by installing transformers not only in the basements but also on more than one floor of buildings more than forty stories high. In the Chrysler Buildings the high-tension feeders, therefore, are carried direct to substations with transformers on the thirtieth, sixtieth, and seventy-fourth floors, while in the Empire State Building there are substations on the forty-first and eighty-fourth floors in addition to that in the sub-basement.

The Empire State Building covers an area $420 \mathrm{ft}$. by $200 \mathrm{ft}$., and its 86 floors can house some 40,000 persons, or as many as a fair-sized town. Illumination is provided on a liberal scale, and the estimated lighting load is $6000 \mathrm{kw}$., while for the lifts, fans, pumps, and other plant electric motors of a total of 9600 horse power are installed. The substations are fire-proof brick structures and each contains four or five $600 \mathrm{kw}$., 13,800/200volt transformers. The main vertical cables are rated for a pressure of $15 \mathrm{kw}$. and are about $3 \mathrm{in}$. in diameter with an approximate weight of $6 \mathrm{lb}$. a foot, and in the article referred to is an interesting account of the methods adopted for placing them in position and securing them.

\section{University and Educational Intelligence}

Birmingham.- - Under the will of the late Mr. James Gittins Chidlaw, of Edgbaston, a member of the Court of Governors, a sum of more than $£ 10,000$ will be put at the disposal of the Council of the University for the endowment of soholarships.

Mr. E. J. W. Barrington of Oriel College, Oxford, has been appointed lecturer in zoology, and Dr. F. C. Champion of St. John's College, Cambridge, assistant lecturer in physics, at University College, Nottingham.

THE Council of the Institution of Naval Architects has awarded the Martel scholarship in naval architecture (1932), valued at $£ 130$ per annum for three years at the University of Liverpool, to Mr. H. G. Herbert, of Sheerness Dockyard, and the Earl of Durham prize to Mr. N. H. Young, of Devonport Dockyard.

A SURVEY of industrial education in the United States of America has been published by the Office of Education, Washington, as Bulletin No. 30, 1931. Among recent developments is noted the more general recognition of the importance of maintaining close contact and co-operation between the school officials and industrial firms. Committees composed of representatives of employers and employees have been especially valuable in selecting the courses to be included in the training programme, in securing properly qualified teachers and adequate equipment, and in the organisation of instruction so as best to meet the needs of industry. There is yet lacking, however, a sufficiently high degree of correlation between the courses provided in the schools of a given locality and the needs of the dominant local industries. Increasingly the public schools accept responsibility for vocational guidance with the view of placing their pupils in suitable occupations, and increasing interest is manifest in occupational information courses. Progressive specialisation in industries has led to corre. sponding specialisation in the schools, and the number of separate courses has been further increased by the inclusion of training for a number of semi-skilled occupations for which a short period of school instruction is now held to be worth while. Evening school work has received more attention, because money spent on training persons already employed yields a more certain and immediate return than pre-employment training. The increasing use of electricity on the farm and in the home is stimulating the development, even in small schools, of courses in simple electric wiring, the operation and maintenance of electrical appliances, and other instruction in applied electricity. Similarly, a belief that aviation will constitute a principal method of transportation in the future is leading to the provision in secondary schools of courses in model aircraft building, etc.

\section{Calendar of Geographical Exploration}

Sept. I3, I 898.-Capt. M. S. Wellby's Explorations

Capt. M. S. Wellby left Berbera on the north coast of British Somaliland, penetrated to the Omo River, and thus entered Lake Rudolf. He then turned northwest and explored part of the course of the Sobat River. In 1896, Wellby and Lieut. Malcolm had carried out a journey in Tibet, crossing the country from Leh to Kuku Nor, afterwards following the Hwang-ho and reaching Peking. This journey filled in many previously blank spaces on the map of Tibet.

Sept. 14, 1927.- The Norvegia Expeditions to the Antarctic

The Norvegia, a vessel fitted out by Consul Christensen, left Sandefjord harbour to begin that series of antarctic researches which has added so much to scientific and especially oceanographical knowledge of the region. Various scientific workers and aeronauts have taken part in the Norvegia's work, and, under the leadership of H. Rüser-Larsen, Queen Maud Land, Ragnhild Land, and Princess Martha Land were discovered. Early in 1931 the Norvegia completed the circumnavigation of the antarctic continent. The Russian explorer, Bellingshausen, in 1819-21, had previously made the circumnavigation of the continent in high latitudes, while Cook and Biscoe had made similar journeys in somewhat less high latitudes.

\section{Sept. 15, 1587.-Davis Strait}

John Davis arrived at Dartmouth after his third arctic voyage, during which he had pushed through the strait named after him into Baffin's Bay and coasted the west of Greenland to $73^{\circ} \mathrm{N}$. On his first voyage, in 1585 , Davis had sighted southern Greenland, which he called the Land of Desolation, had crossed Davis Strait, explored part of the Canadian archipelago, and had penetrated some distance into Cumberland Sound. On his second voyage, in 1586, he again reached the north-east coast of America. His voyages pointed the way to the true north-west passage, though it was not given him to reach it. $\mathrm{He}$ added much to the knowledge of the coasts of Greenland and north-east America. In 1591 he accompanied Cavendish on his voyage with the object of "searching that north-west discovery upon the back parts of America". After the rest of Cavendish's party had turned back, Davis continued the journey and discovered the Falkland Islands. He was killed by Japanese pirates when off Sumatra in 1605 . Davis is also entitled to fame as an inventor; his back staff and double quadrant held the field long after Hadley's reflecting quadrant had been introduced.

\section{Sept. I7, 1776.-Basin of the Colorado River}

Father Garcés, a Franciscan missionary, reacheo Bac. He had set out in 1775 from the Yuma country, travelled from the mouth of the Colorado to Mojave,

No. 3280, VoL. 130] 